\title{
Rhapsody of Religious Violence in Nigeria: Dynamics, Case Studies, and Government Responses
}

\author{
Titus S. Olorunnisola $(\mathrm{PhD})$ \\ Department of Missiology, University of Divinity \\ ACOM/Sydney College of Divinity \\ VIC 3052, Parkville Melbourne Australia \\ E-mail: titusolorunnisola@gmail.com
}

Received: Sep. 3, 2019 Accepted: Nov. 13, 2019 Published: Jan. 15, 2020

doi:10.5296/ijssr.v8i1.15394 URL: http://dx.doi.org/10.5296/ijssr.v8i1.15394

\begin{abstract}
This article examines the commonalities in the case studies of religious cum political violence in three states of northern Nigeria. The dynamics of religious violence in Nigeria attest to the existing social theories of conflict. The article concluded that there exist certain frenzy elements that have aided the occurrences and the spread of the wave of violence bearing upon multiple factors. The article suggested that a holistic approach which draws insights from the series of the existing cases of violence would be instrumental in propounding a lasting solution to the recurrent incidence of religiously motivated violence in Nigeria.
\end{abstract}

Keywords: religious violence, religious rhapsody, northern Nigeria, ethnicity, politics 


\section{Introduction}

Nigeria has been intensely ravaged by a wave of unprecedented violence notably since the early 1980s. The manner in which one religious violence has been addressed in one state has generated a recurrence of similar violence in the neighboring states. Osaghae and Suberu (2005, p. 4) have postulated that in "virtue of its complex web of politically salient identities and history of chronic and seemingly intractable conflicts and instability, Nigeria can be rightly described as one of the most deeply divided states in Africa." The patterns and dynamics of religious violence in northern Nigeria is unique; it contains a frenzy-like element which when fully attuned, is difficult to halt.

This article takes a painstaking look at some case studies of interreligious and politically motivated conflicts in three states and examines the factors which thrust these crises. My methodology is an interpretive and analytical method. I will take a cursory look at the patterns of conflicts in Nigeria and proceed to document narratives of devastating religious cum political violence experienced in the 1980s until the new millennium before a petite analysis. This will be followed by some observations on the ways in which the government has responded to these crises at various times. The article concludes by drawing some implications and making salient recommendations that may be instrumental in the cessation of religious and political violence in northern Nigeria.

\section{An Overview of the Religious Conflicts in Nigeria}

Social theorists have rightly suggested that origins of conflicts or violence can be traced to multiple factors (Kieh Jr. \& Mukennge, 2002; Kieh Jr., 2002; Tidwell, 1998). Social, economic, political, historical, psychological, cultural, and religious factors can independently or organically form the bedrocks of 'contingent elements' or 'trigger elements' in a violence situation (Keih, 2002, p. 12). All these features help us to identify different forms of violence within the social strata. It is inevitable for conflict to ensue as a result of contestation for influence and recognition, scuffle for economic or political power or resources, and, most importantly as a consequence of solidarity to a combination of some of the factors already mentioned.

Different patterns of violence are identifiable in Nigeria. Firstly, there were ethnic and boundary conflicts which ended up in the form of violence. Land disputes are one of the architects of violence in communities across the length and breadth of Nigeria. There had been battles over boundary adjustment in various parts of the country (Alubo, 2006). The well-known examples include the Ife and Modakeke crises and Ijaw and Itshekiri crises among others. Secondly, we can also identify intra-religious violence. The clash among members of the same religious group on the bases of a clique ideology and convictions have sometimes escalated beyond the scope of the religion to other facets of the national life. Thirdly, there are records of inter-religious conflicts. This is the most common form of violence. There were instances where some misunderstandings erupted between members of two opposing religious groups only to end in unleashing a skirmish on the members of society who were not directly involved in the argument. Fourthly, we can also name violence that occurred purely on the ground of politics. Similar to instances of intra-religious violence, 
political violence has at times resulted in the release of bottled-up anger with an undertone of religion. There is hardly an instance where one form of conflict mentioned above is absolutely exclusive of the other.

\section{Case Studies of Religious Crises}

In presenting the case studies of religious violence, it should be noted that these crises did not follow chronologically. In most cases, these crises ensued sporadically so that an area which experiences violence at one time still encountered another cycle of similar violence years later. This approach will be helpful in deconstructing the seeming difficulties of the sequence of the occurrences. The focus of the accounts presented includes the sparks to the violence, internal dynamics, major active players, and responses of government and its agencies. Finally, the accounts presented here cover three states; Kano, Kaduna, and Plateau all in northern Nigeria.

\subsection{Kano Religious Conflicts: 1982, 1991, 1995}

Kano is a city located in the core northern part of Nigeria. It is prominent as a commercial centre and the capital of Kano State, a predominantly Muslim state but a significant amount of Christian community cannot be denied in the city and the entire state.

On the $30^{\text {th }}$ October 1982, the Muslim Students' Society (MSS) raised a protest against Christians in the city of Kano due to the location of a church building, St. George's Anglican Church in Fagge. The reason was its proximity to the central mosque (Boer, 2003, p. 39-40). Before this hullaballoo surged, the said church had been visited by two important personalities in the year. In February, Pope John Paul had visited Nigeria followed by the Archbishop of Canterbury, Robert Runcie in April. The Anglican Church in Kano decided to commemorate the historic visit of the Archbishop of Canterbury with the foundation-laying of a new auditorium. The dramatic part of this story is that the first church building was constructed in 1933 while the mosque was built between 1968 and 1970. The Dutch Missiologist, Jan H. Boer who worked for over thirty-five years in northern Nigeria gave an eyewitness account of the state of events between the church and the Muslim community before this crisis:

"In 1933, when the mission compound was built up, I was there. The compound then stood within the radius of about 1000 yards on each side from Sabongari and Fagge. There was no building of any kind anywhere near it... right in front of the church, almost covering the passage, a court and a police station are built. This appeared to have choked up the compound and there was hardly any way out. On the day the mosque was opened, Muslim worshipers filled the mission compound and worshipped undisturbed" (Boer, 2003, p. 40).

The testimony above was given by Justice Haruna Dandaura before a Committee appointed by the Kano State government to investigate the occurrence and report back to the state government. No one could imagine that there would ever be a crisis because of the foundation-laying of a new church building. The protesters insisted on demolishing the church building but there was an intervention from the police who succeeded in preventing the demolition of the church building, although around forty-four people were reported killed 
(Boer, 2003, p. 40).

On October 29, 1991, there was another episode of religiously motivated violence in Kano. The Christian community invited the German Pentecostal Evangelist, Reinhard Bonnke to lead a week-long crusade in the city of Kano. Bonnke has a reputation for charismatic preaching and consequently inviting people to say 'yes' to Jesus. His crusades always attract massive participants, both at the evening programs and ministers' forum. Some would travel from neighbouring states, and even neighbouring countries, to listen to him. Bonnke's evangelistic crusades are characterized by heavy publicity; posters are often printed and pasted around the hosting city walls, streets, schools, churches, and other public places. Such phrases as "Jesus Fire Crusade", "Kano City Crusade for Christ" are popular appendages appearing on posters and handbills for this crusade.

Nguvugher (2010) itemises three likely triggers for this upheaval. The mention of the word "crusade" which in that context was a sensitive word connotatively- reminding the Muslims of the wars of the previous centuries which were synonymous with The Crusade Various devastations accompanied the crusades (especially the Jihad) and thousands of lives were lost. The coming of Reinhard Bonnke would possibly refresh the memories of the historic past (Nguvugher, 2010, p. 124). Besides, Kano State is predominantly an Islamic state as noted earlier. Such massive publicity for a Christian program using the media may have been understood as an attempt to convert the entire state to Christianity. Most of Bonnke's previous evangelistic crusades had witnessed massive conversions of people to Christianity, whilst several other people also rededicated themselves to Jesus Christ. Prior to this time, the local organizing committee of the Christian Association of Nigeria (CAN) had written to the state government to secure an approval. The approval was given and CAN was to make a compulsory payment of ten thousand naira. When the money was ready to be paid, it was increased to thirty and then fifty thousand naira, possibly to discourage the use of the Race Course where CAN had proposed to hold the crusade. Islamic fundamentalists vowed to stop the crusade. Intelligence reports and verbal notices began to reach CAN. As a result, the CAN decided to change the venue of the program to St. Thomas Catholic Church, Sabon Gari.

Nevertheless, the Muslim fundamentalists attacked the crusade leading to the death of two hundred people. Houses and cars were set ablaze with shops located nearby invaded, leaving a lot of people homeless. In response to the above, Christian youths immediately mobilised and responded in defence of themselves. However, the defence strategy turned out to be a reprisal, leading to the burning of over twenty churches, one mosque and several people sustaining various degrees of injury under two days of this riot (Boer, p. 42-46). This was quite different from other attacks where the Christian community was afraid to defend itself.

The Muslims believed they were justified in their actions. Three events led to this occurrence. Two Islamic preachers had been denied visas to enter the country; Louis Farrakhan, a Muslim leader in the United States, and the South African Muslim polemicist and apologist, Sheik Ahmed Deedat in 1987 and 1990 respectively. The Muslims had also been denied the use of the Race Course for the celebration of id al-maulid, a festival marking the birth of the Prophet Muhammad by the government. Whereas, it was granted for Christians to host a 
crusade program. They reasoned that while Muslim preachers were denied entry for Islamic activities, a Christian evangelist was allowed in, and was also given permission to use the Race Course. Consequently, they needed to stop them (Nguvugher, 2010, p. 125).

The series of pandemonium that has been witnessed often have remote and immediate causes. In some instances, it built up over time and became unleashed at the highest point. This is the best way to describe the Kano riot of 1995. Boer (p. 46-50) states that three major events had orchestrated the riot. One was that one Akaluka, an Igbo trader in Kano had used pages of the Qur'an as toilet paper, and as a result, he was kept in protective custody for his own safety. Afterwards, an angry mob broke through the prison and beheaded him while his head was paraded in the town. That someone could be beheaded under protective custody raised some unanswered questions. The second incident was when a woman, who hails from the southwest had boarded a vehicle, but the conductor gave the wrong amount of change. The woman requested for a balance of her change but the conductor refused. The angry mob was ready to massacre her except for the intervention of the police and military. The third is that two Hausa women parked their car in front of an Igbo shop. Two Hausa men burgled the car and stole a bag. The Igbo trader managed to identify the burglars and the incident was reported to the police. The Police pressed charges but released the men on bail. Fellow sympathizers began to quarrel with the Igbo man. Other fellow Hausas supported the rioters against the Igbo man, who was considered an infidel. The fight escalated from there and the Muslims seized this opportunity to massacre any Christian that could be found.

The rioters assembled at St. George's Anglican Church which had been the subject of the riot in 1982 and set the building ablaze. The priest in charge of the church narrowly escaped with his family. Every other person who could not chant "God is great" in Arabic fell, a victim. The events narrated above sent signals to Christians that Kano was an Islamic state. Fliers appeared overnight from the Muslims:

"This is to inform you that for your own interest and life security, you are seriously advised to pack out of Kano metropolis with immediate effect and in no given time, otherwise your life will be in danger. And for your information no authority can protect you from whatever calamity that will befall you if you fail to comply" (Agi, 1998, p. 96).

The Christians within Kano had been pushed to the wall. They looked for various ways to defend themselves through the arms of the flesh and with the words of their mouth. The state government responded by deploying a team of mobile police and military to assuage the situation. The vicar of the burnt church, who incidentally belonged to the same Igbo ethnic group as the Akaluka who was beheaded, gave an uncompromising response in view of the experiences of the time. Boer reports;

“(Christians of Sabon Gari) don't rely on the police. They don't rely on the Army. But I must tell you that Sabon Gari is not an easy field to swallow. As small as we are, there is nothing we don't have, but, moreover, we have God. We're ready. This Sabon Gari can face the whole of Kano State and burn Kano State... But for the fact that we held our youth, eh! They were ready to face the Mobile Policemen....But any day they attempt to come into this area, nobody will be safe. The Emir, the Governor, the police, nobody will be safe. I don't want to 
tell you how but it will happen. I must tell you that we're prepared” (Boer, p. 49).

Captioning the Kano series of combats between Christians and Muslims gives an idea of how a fundamental Muslim thinks in a crisis situation. It is obvious that some of the causes enunciated above are issues that could have been settled amicably without necessarily leading to a bloodbath. Considering the government's responses to these clashes, it is common for the government to set up a committee of enquiry to investigate the causes and make recommendations. Unfortunately, the reports of most of the committees set up didn't see the light of day. In the 1982 riot, Christians were told to remove the church from its location, although strong evidence detailed the distance in the times of construction of the church and Mosque, in favor of the church. A dusk to dawn curfew was often imposed to reduce the effects while a state of emergency was imposed on the affected state in recent times. A combination of soldiers and mobile police were used to curb the effects on the citizens. Generally speaking, the government's response has often been in the form of apathy to the cry of the Christians, no compensation for affected persons, and culprits never brought to book. This has not eradicated the Muslim-Christian conflicts as it has also been experienced with degrading effects in Kaduna State.

\subsection{Kaduna Religious Conflicts: 1987, 1992, 2000, 2002 and Beyond}

Kaduna, like Kano, is the capital of its state. It is also one of the oldest northern emirates. Besides, it has economic and political importance as the capital city of the old protectorate of northern Nigeria under British colonial rule. It has 23 Local Government Areas with a population of slightly over six million people, with ethnic, political and religious divides. The northern section of Kaduna is the home to Hausa/Fulani who are predominantly Muslims while the Christian minority ethnic groups reside in the south. Kaduna is traditionally known as a Christian-populated state. When counting the effects of the inter-ethnic cum religious riots in Nigeria, Kaduna will be rated to have had the most devastating effects on both human and economy. The narratives below inform that assertion adequately.

The 1987 riots began at Kafanchan, a city in the southern part of Kaduna State. Analysts are divided along religious lines as to which religious group began the riots (Nguvugher, 2010, p. 129). The issues leading to this riot are the fundamental orthodox doctrines of the Christian faith. Christian Student Fellowship at Kafanchan College of Education staged a program featuring the life and work of Jesus Christ. The guest minister, Rev. Abubakar Bako, a Muslim convert, is known for his extensive quotations from the Qur'an during his preaching. The presence of an ex-Muslim invited to lead a Christian program in an environment already boiling internally for a few weeks attracted some Muslim students to attend the Christian Student Fellowship, expecting an offensive utterance or quotation from the preacher.

The preacher quoted two Qur'an passages which allegedly triggered one female Muslim student, Ai'sha Umaru, to interrupt the preaching by seizing the microphone (Boer, p. 52; Nguvugher, p. 130). To Ai'sha, misquoting and misinterpreting the Qur'an is a gross abuse of Prophet Muhammad. The school authorities were involved, the Christian fellowship was asked to apologize to their Muslim counterparts. They did but it was too late. "A fight ensued and soon escalated into a full-blown ruckus, with sixteen students seriously injured and a 
church burnt along with the school mosque. Bako escaped through a barbwire fence and remains a wanted person by Muslims" (Boer, p. 52). The following Sunday, Christian students were meeting at a church in the town but the Muslims located them and disturbed their activities with fierce attacks using various weapons. The fight escalated from the College campus to Kafanchan town and other churches in the neighboring towns like Zaria, Katsina, and Kano.

There was massive destruction of government property on the campus at $A B U$ and in the various affected towns and states. Over one hundred and fifty-two churches were reportedly destroyed statewide, five mosques vandalized, and several people lost their businesses in this fracas. The roles of the police and media were prominent in escalating this crisis. The effects could have been minimized in most of the towns and churches affected. The matter was promptly reported to the police for appropriate action or protection in the face of the looming danger and the police promised to monitor the situation only to refrain from any concrete action. Again, the media also fueled the crises by reporting in the initial stage that Christians were killing Muslims at the Kafanchan college campus. This led the Muslims to mobilize with reinforcements thereby making the matter worse.

The government set up a commission of enquiry to find out the causes and make recommendations to prevent a future occurrence. The trend in the period under review is such that when one crisis ends, another version begins in another part of the north.

The Zangon-Kataf riots of February 6, 1992, remains very fresh in the minds of both northerners and southerners equally because of its dimension and the monumental destruction it left on its victims. It began by the Kataf people of Southern Kaduna with the Hausa-Fulani Muslim community as the target. This crisis occurred over the proposed relocation of a local market in view of the shortage of stalls. The Christian Kataf community was happy about this development but the Hausa traders were unhappy about it. They claimed the new market site had not been developed. Armed Kataf youths had allegedly unleashed violence on the Zango community in protest. The security officials could not assuage the situation. "The damage was great. Millions of nairas of vehicles, farms, and equipment were destroyed, including thirty-eight cars and nine motorcycles, 133 houses and twenty-six farms. Ninety-five people were killed, while 252 went to the hospital for treatment of wounds" (Boer, p. 58). Most of the casualties were Muslims.

This, however, was not the end. While there was a lull for a short time, a new situation arose when a source, as reported by Boer, has it that Emir of Zaria who was in charge of the area, had visited the Hausa community of the Zango with some gift items, though excluding the Kataf people in the same area. Additionally, the state government's relief agency went to donate some gift items to the Zango people but neglected the Kataf community. After the visit, the Emir of Zaria invited the Kataf people to Zaria. These earlier acts were interpreted as supporting only the Zango people so they, in turn, ignored the invitation. This led to another fight. Hausa people then carried their dead to Kaduna city to 'whip up' sentiments which then attracted sympathizers to fuel the fight for them. Hence, the Muslim youths took to the streets, "indiscriminately burning anything that symbolized Christianity, and killing or maiming 
anybody suspected to be a Christian" (Agi, 1998, p. 86). The Christians also retaliated. The crisis spread to Kaduna city and Zaria. The death toll in the crisis was numbered between 4,000 and 5,000 people apart from those injured. As part of the government response, the local government was dissolved and some of the civil servants were sacked for their roles in this crisis. In the aftermath of this crisis, it was assumed by many Christians that the manner in which it was managed by the government allowed the riot to escalate. Over three hundred people were arrested including prominent Kataf people who were believed to have instigated the riot. A prominent Kataf army general, Zamani Lekwot was given a death sentence but this was later converted to a short jail term (Falola, 1993, p. 221). An economic issue in the community eventually led to religious violence.

The beginning of the new millennium, when many were expecting a new order, betrayed their expectations because of crises. In fact, it marked a major shift in the debate on the sporadic crises experienced in the Nigerian landscape. The turn of the $20^{\text {th }}$ century witnessed a fresh debate on Shari'a law. This was not the first or second time Nigerians were debating Shari'a law and its implementation (Falola, p. 77-102). Some northern state Governors unexpectedly intimated the populace of their plans to introduce Shari'a law in their states. Shari'a laws were previously applied to the personal laws; but from this time, it was to be applied to criminal laws. It was first raised in Zamfara State and then spread to Bauchi, Kaduna, Yobe, Kano and other parts of the northern states. There is a uniqueness about Kaduna State when compared to other northern States; there are about thirty ethnic settlers around the southern part of the state. Northern Kaduna has Hausa-Fulani settlers predominantly while southern Kaduna is home to many Christians. With a significant Christian community, the Christians view themselves as a majority and stood against the implementation of Shari'a law in Kaduna State. The governor, as well as the House of Assembly, set up different committees to consider the issue and make recommendations to the government. These committees were not able to give any substantial report that could calm the atmosphere of suspicion and tension already building in the state. It is fascinating to note that the governor Ahmed Markarfi was a Muslim, while his deputy Stephen Shekari was a Christian. The Christians did not trust the committees set up. All the while the Muslims were mobilizing and clamoring for Shari'a.

In an attempt to stop the proposed Shari'a law, the CAN branch of Kaduna State organized a mass protest of over 50,000 participants on February 21, 2000 marching to the State House of Assembly and the Government House (Boer, p. 64-65). However, the peaceful protest turned bloody. The leaders of the protest were awaiting an audience with the deputy governor, as the governor had travelled abroad on medical reasons when a report reached them that the Muslims had started attacking their families and businesses back home. The protesters immediately dismissed themselves to return home to defend their families, businesses, and church buildings. The mob then used that instance to loot various shops and set houses ablaze. Churches were incinerated, mosques were not spared in some places, corpses littered the streets, petrol stations set ablaze, residential houses were torched and the remnants deserted the area. Businesses worth millions of naira were lost. Many of the people who could not recite verses of the Qur'an became victims, slaughtered by the angry mob holding various injurious weapons. When the then-President Olusegun Obasanjo visited the city, it was but a 
ruin! He exclaimed with utter dismay for lack of greater expression:

"The devastation was so massive, it seemed as though Kaduna had overnight been turned into a battlefield. My visit confirmed... all the reports I had been getting- the mindless killings and maimings, the wanton destruction of property, the fear and uncertainty on the faces of those who survived the carnage, and the pervasive mutual suspicion" (Boer, p. 78).

The fight was fueled with the report that the Muslims were transferring their families and relatives to other areas of Kaduna, a predominantly Muslim dwelling. Rumors spread wide that this was meant to embark on a fresh clash with the Christians. This prepared the Christian groups for further attacks. The one-sided report of Radio Kaduna aggravated the situation. In the interim, both Christian youths and Muslim youths were already acquiring firearms in the event of an outbreak, apparently eager to put them to use. This situation gave them an opportunity to experiment with their arms. The youths in major areas like Tudun Wada, Kawo, Kakuri, and Rigasa started killing one another. This bloodletting spread to other parts of the state like Zaria and on the extreme parts of southeastern Nigeria because the Igbos embarked on reprisal on the Muslims and even Hausas in Aba, Onitsha, and Owerri, avenging their relatives killed in the Kaduna crises.

It took the military with armored tanks to lay the situation to rest. The president summoned the meeting of the National Council of States for the purpose of the intervention. A decision was reached that the status quo be maintained but the governor still went ahead to enact the Shari'a laws under the guise that the matters pertaining to Christians will not be applicable under the Shari'a laws. Markafi went ahead to implement a modified brand of Shari'a law in the state. (Note 1)

In a bid to implore all the concerned parties to embrace peace to forestall similar future occurrences, eleven leaders each of both the Christian and Muslim groups were invited with the government officials for a harmonious discussion, followed by the signing of an agreement to preach peace and allow peace to reign in their various domains. Their commitment was to:

"...work with all sections of the community for a lasting and just peace"; condemned all forms of violence and sought to "create an atmosphere where present and future generations will co-exist with mutual respect and trust in one another"; and announced the establishment of a "permanent joint committee to implement the recommendations of this declaration and encourage dialogue between the two faiths" (Kaduna Peace Declaration of Religious Leaders, 2002, August).

The next major crisis that loomed in the city of Kaduna shortly after two years has since then been called the "Miss World riots" 2002. Because the 2001 contest was won by a Nigerian, Nigeria was selected to host the 2002 edition at Abuja, Nigeria's Federal Capital Territory (FCT). The Miss World pageant is an annual beauty contest held worldwide and detached of any religious connotation. Certain controversies emerged when Nigeria was selected to host the event leading to further violence. On March 21, 2002, while still recovering from the Shari'a crises in most states of the north, one Ms Amina Lawal was sentenced to death by 
stoning under Shari'a law for allegedly having a child out of wedlock as a result of a rape. This happened in Katsina State, the very first place the Shari'a law was imposed on the citizens. Strong appeals launched against the judgment were thrown out. As a result, there was pressure on the participants to boycott the beauty pageant before arriving in Nigeria (ThisDay, 2002, November 23). Secondly, hosting a beauty pageant event during the concluding week of Ramadan fasting also added fuel to the fire. Ramadan, according to the Islamic tradition, is a holy month when the Muslim faithful are encouraged to re-consecrate themselves to Allah. Hence, hosting a pageant competition was deemed offensive by the perpetrators in the various parts of the north. These two issues led to the third, which was the primary trigger-factor of this crisis.

Isioma Daniel, a ThisDay newspaper journalist wrote an article on the $16^{\text {th }}$ November in which she ostentatiously described the beauty of participants in the beauty pageant, concluding that, if Prophet Mohammad was alive, he would have loved to marry any of them. She puts it pretentiously:

"What would Mohammad think? In all honesty, he would probably have chosen a wife from one of them. The irony is that Algeria, an Islamic country, is one of the countries participating in the event" (Nguvugher, 2010, p. 136).

This statement was offensive to the entire Muslim community. By November 20, Muslims took to the street in Kaduna, in a protest presumably a peaceful demonstration at first. It was later hijacked by another group of hoodlums resulting in a vicious cycle of vandalism beginning with the ThisDay's branch office in Kaduna. Private and public properties, businesses and churches were torched or damaged. At the end of the three-day crisis, The Guardian (2002, November 30) reported that "58 churches were attacked and at least 215 people were killed." The Zamfara State government issued a fatwa on Isioma, calling for her death while she was forced to flee to the United States of America on asylum. Three hundred and fifty people were arrested in connection with this riot. The dynamics of this event is suggestive of the spirit of violence which can hardly be pacified once it is started. ThisDay newspaper apologized to the entire Muslim community in the nation, displaying the apology conspicuously on the cover page for four days from November 16, with Isioma's resignation for her journalistic blooper. But this did not stop the premeditated violence.

The venue of the beauty contest was shifted to London, the United Kingdom where it was held on $7^{\text {th }}$ December. The legitimacy of the source of the issuance of the fatwa on the embattled journalist was questioned in line with the Islamic tradition. Only a religious leader is legally allowed to issue such a religious verdict, not a government official like a deputy governor.

Prior to the appearance of ThisDay article, the declaration of Nigeria as the host country did not meet with the goodwill of some conservative Muslims in the north who associate the competition with all sorts of sexual impropriety like half-naked dresses and promiscuity. Consequently, there were rumors of underground threats before the arrival of the contestants. It could be argued that the organizers would have considered another country for hosting this competition except for the intervention of then-president of Nigeria, Olusegun Obasanjo, who 
calmed the rumors that the situation was under control and that the event would not be held in a city highly populated by Muslims. He assured the international community of the safety of the contestants. Announcing Federal Capital Territory (FCT) Abuja was later interpreted as undermining the presence of Muslims in Abuja. As the violence began the President blamed the media for the uproar, claiming it is irresponsible journalism committed against Islam, but later pleaded with the entire nation to remain calm. The violence spread to Abuja but the police quickly arrested the situation, unlike Kaduna where the police did not give immediate attention. The overview of this riot presented Nigeria erroneously to members of the international community as an Islamic country. Amina later gained her appeal in 2003. The overbearing consequences of this riot have also been stressed. For instance, Human Rights Watch (2003, July 27) indicates that about two hundred and fifty people were killed while between twenty and thirty thousand people were displaced in addition to extrajudicial killings.

The whole of the Kaduna episodes of violence with various shattering effects is a practical demonstration of the interconnectedness between ethnicity, religion, and politics. The government, which ought to be non-partisan in the peace-building process is mostly found guilty of taking sides in the whole complex web of violence. The ritual of setting up one committee of enquiry to give a critical look into the causes of violence in different parts of the affected states has gradually lost its relevance. The cases of Kaduna State have shown that the government of the time was a colossal failure with regards to security and mutual co-existence in the state. Part of the recommendations given on the 2000 crisis, which the state government also agreed to, was that affected areas, churches and mosques will be adequately compensated. As at the time of another crisis in the year 2002, these recommendations have not been implemented. The changing face of similar violence has also occurred sporadically as we shall see in Plateau State.

\subsection{Plateau Religious Conflicts: 1994, 2001 and Beyond}

Jos - the capital of Plateau State - has a relatively long-standing era of peace compared to all other northern states. It has a history of having Christians as the dominant indigenous people and settlers who, unlike most of the northern states, had lived peacefully together with Muslim/Fulani northerners who had migrated to the state from other northern states in the early part of the $20^{\text {th }}$ century. This peaceful co-existence earned the Plateau State the slogan "Home of Peace and Tourism" among other states of the federation. This condition of peaceful co-existence was overturned beginning with the crisis of 1994.

Historically, no part of the Plateau State fell to the Islamic Jihad of the $19^{\text {th }}$ century. Perhaps, this is the one reason why the state has a majority Christian population. During the process of political groupings in the colonial era, part of Jos north was placed under the rulership of the Emir of Bauchi who was appointed from an Islamic descent. The Emir, in turn, appointed a Chief to oversee Jos until 1926 when the colonialist removed Jos under Bauchi and installed an indigenous chief. This decision remained unchallenged until 1987. In 1987, a Muslim politician Saleb Hassan was said to be inciting youths of Jasawa - Hausa/Fulani settlers - in Jos north to rise and reclaim the right of chieftaincy back from Jos as their legitimate right. 
The problem lingered for years and the peak of this was the riot of 1994. In 1994, the military administrator of Plateau State, who himself was a Muslim, appointed a Muslim member of Jasawa tribe to the position of the Chairman of Jos North Local Government Area. While the Jasawa people were glad of the gradual breakdown of the domination of the traditional people, the decision did not go down well with the traditional Jos people, who interpreted it as a gradual fulfilment of the internal war that began in 1987. Hereafter, they decided to embark on a massive but non-violent protest against the decision. Seeing the signal, the appointment was suspended and the Jasawas took offence, went on a rampage, caused substantial havoc, killings, and looting. The police and military were invited to calm the situation. The tension of that situation remained as none of the parties 'gave up its claims.' This broke the peace of the Plateau State; the situation has never been the same since.

Friday, March 22, 1996, was a day of the interruption of regular activities due to a clash between Christians and Muslims not far from the Jos Central Mosque. Weeks before, tension had risen very high in view of the violence associated with Local Government elections held nationwide, in which a thirty-five-year-old Christian man was killed while challenging a group of rogues who were allegedly engaging in multiple voting. Azi Chai was killed in Agwan Rogo, a Muslim-populated area. On that day, the CAN gathered at the Church of Christ in Nigeria (COCIN) at Sarkin Mangu Street while in procession for the burial of this young man. The relationship had worsened because of the killing, added to the fact that the Christians could not pass through the street on this Friday as the Muslims blocked the road because of the Jum'aat prayer. The Christians boldly dismantled the barricades which led to a fight on the street. Nguvugher (2010, p. 149) as supported by Agi (1998, p. 106) reported that "many people were injured and property estimated as running into thousands of naira was damaged in the skirmish."

The city of Jos went into a state of frenzy again on September 7, 2001. History repeated itself as one Alhaji Mohammed Muktar Usman was appointed Chairman of the Jos North Local Government Area as well as the co-coordinator of the National Poverty Eradication Program (NAPEP), (Note 2) a decision unacceptable to the indigenes. There are two other causes that helped ignite this violence. The first is that a Christian woman passed through the middle of a group of Muslims during a Jum'aat prayer. The Islamic vigilante beat her up and the Christian youths retaliated to the extent of burning the mosque. The second is a pamphlet distributed by the Muslims in the area in response to an earlier Christian group's provocation. When the position of the Jos North Council Chairman was announced, the Christian youths came out en masse to protest, holding various placards with different inscriptions to show their displeasure. The Muslim youths equally responded with provocative placards arguing that Jos North Local Government was simply created at their request. Jos North indigenes reasoned that the settlers were claiming their own land thereby losing their traditional heritage. These responses in an already tense atmosphere sparked the ferocity in the entire local government and all through the state. The violence escalated from this area to other parts of the state and other neighboring states like Kano, and Onitsha in southeastern Nigeria. The September $7^{\text {th }}$ crisis lasted six days with a death toll estimated at one thousand people. The Home of Peace and Tourism then turned to a "state of pieces and terrorism" continuing 
to 2002, and 2003; with sporadic violence in places like Langtan-Wase, Minchakpu where a figure put at 500 people died, and over ten thousand people were displaced. In the Jos 2002 crisis, the ultramodern market complex was torched leading to a colossal loss for a lot of business owners and traders within the complex and its environs. Indirect clashes which are an offshoot of the main one in Shandam, Langtan South, Langtan North, Wase and Kanam, Basa Local Government Areas, resulted in a lot of churches, mosques and residential houses razed to ashes. Besides, a large number of people were declared missing.

The Jos episodes of crises can best be described as a "battle for supremacy" between 'indigenes and settlers' beginning in 1994 and had been channeled through religion between Christians and Muslims using politics as a tool. An offshoot of this crisis has continued unabated until recent times in various part of Plateau State with major effects. The tension became heightened again in Yelwa, Mikang, Barkin Ladi, Shendam, and Wase in the year 2004. On May 2, 2004, there was an extensive massacre as a group of militant Christians of the Tarok tribe attacked a Muslim community of Yelwa town leading to the death of six hundred people. This happened as a counter-attack to the previous attacks on the Christian community a week earlier. However, the situation repeated itself in the Muslim-dominated Kano, where the Muslims bombarded Christians in the state with fierce violence killing fifty people. The crisis was almost beginning to threaten the corporate existence of Nigeria when the then-president, Olusegun Obasanjo had to declare an emergency rule in Plateau State. It was becoming imminent that it would result in the emergency rule as the violence was already escalating to other parts of the country. The situation persisted all through year 2011and 2012. On July 8th, 2012, the deaths of a senator representing Plateau North district and Gyang Fulani, a Majority Leader of the state assembly were reported. They were assassinated by alleged Fulani assailants. The killers were dressed in military uniform and killed the two men while four others were injured. Some individuals dressed in the same regalia had earlier attacked several Berom villages, killing mostly the elderly, women, and children. This resulted in the deaths of over forty people, including twenty from the attackers. This is just one of the several attacks in a succession of violence between Jos' Fulani herdsmen, who are predominantly Muslims and the Berom people who are Christians. It was the peak of the happenings around this time (Newsrescue). (Note 3) Various pressure groups, as well as international communities, began to pressurize the State and Federal Government to find a lasting solution to the crisis in Plateau State.

A Commission of Enquiry set up by the Plateau State Government was ending its findings and preparing its report (Vanguard, 2010, p. 3) (Note 4) when the Presidential Panel of Enquiry of the Federal government arrived for its own findings and dialogue among various waring people. (Note 5)

A source, Coalition of All Southerners in Plateau State (Vanguard, 2011, p. 3), comprising people from the southwest (Yoruba), southeast (Igbos) and south-south (Niger-Delta area) recently numbered the losses associated with the Jos crises since 1994. The group claimed that since 1994 Plateau State has lost 1,654 persons and property worth \#970 billion naira. (Note 6) Up to the moment of this writing, the government of Plateau State and the Federal government of Nigeria are engaging in a collaborative effort to resolve over a decade of 
attacks and reprisals in various parts of the state. The trend that is now developing is that of dialogue so as to erase the bitterness of the past and persuade various stakeholders to embrace peace and mutuality through right actions beginning with the government. Crises related to the above have occurred in various parts of the north. The above backgrounds have given birth to a greater, worrisome stance of fundamentalism. Since the year 2010, there had been a shift in the understanding and interpretation of the periodic violence witnessed in the northern part of Nigeria. It is now taking on some dimensions of terrorism.

\section{A Brief Analysis}

The case studies explicated above reveal the nature, patterns, and dynamics of violence evident in most states of northern Nigeria. First, violence in Nigeria on any ground has an element of rhapsody. The perpetrators of violence often initiate it ecstatically with every given opportunity. The euphoric nature of the violence makes it possible to spread easily from one location to another. This is the only reason why it is common to experience escalating violence when the immediate and trigger causes are propelled.

Second, the dynamics of religious cum ethnic violence in the northern part of Nigeria is deeply rooted in grave historical antecedence. Part of this history is to be contrasted in the forceful conquest of the pre-colonial Nigeria by the former British Empire (Falola, 2009). This use of force went down as a legacy of colonization. Besides, the history of Islamic incursion also laid a foundation for the introduction of the Shari'a law in Nigeria. The ascendancy of the Muslim Fulani/Hausa into the political offices, using religion as a vehicle resulted in the hegemony of a section of the northern ruling class and the marginalization of non-Muslims in the northern region (Kukah, 1993). These factors orchestrate internal disintegration to the point of endemic segregation. For example, in the cases of Jos-Plateau religious violence, a group of people was referred to as 'settlers' while others were called 'indigenes.' This appellation, which emerged from historical settlements of people in the state, was one vital cause of crises in the Plateau State. It led to the fundamental question of ownership of the land and whether some people have rights in the state despite a long history of settlement.

Third, violence in Nigeria is eclectic in nature. The case studies above demonstrated that no single reality can account for the outbreak and spread of violence. Multiple factors such as poor economic situation, ideological imbalances, intolerance, identity politics, political manipulation, and religious extremism are major causes in the case of Nigeria. Perpetrators have mobilized gullible people using these factors to initiate large scale violence that has ended in wanton destruction of lives and property. In some cases, ignorance of the youths and low-income earners are incentives for mobilization on the promise of better economic benefits. Some of the Commission of Enquiries set up to investigate the causes and make recommendations to the government have linked the spread of political cum religious violence to the pitiable social and economic conditions of the people involved.

Fourth, religion is a powerful weapon among Africans and it has been misused as a focal point in Nigerian nationhood to create an atmosphere of tension and violence. Religion as a binding force has its own share in the events of violence in decades of Nigeria's existence. 
Religion and politics have always been in close contact in Nigeria so that it is easy to describe this symbiotic relationship perfectly in terms of 'politicization of religion and religionization of politics' (Adogame, 2005, p. 128-139). Afe Adogame is right on this when he cites Orlando Robertson:

"An increase in concern on the part of ostensibly religious collectivities with governmental issues and, secondly, an inflation of interest among those with declared religious commitments in coordinating the latter with secular-ideological perspectives and programmes... politicisation and religionisation are mutually amplifying processes, in that the more 'religious' the state becomes the more it provokes expansion of activities of ostensibly religious actors along political lines" (Adogame, 2005, p. 126).

It is extremely difficult to separate religion from the happenings in the political terrain. Politicians often bring religious factors to bear in the political process, mobilization, and electioneering campaign. Religion, therefore, is in the fore of most political and economic moves and has also sharpened it in so many ways.

\section{Government Responses to Religious Violence}

\subsection{Economic Approaches}

The Nigerian government has undertaken different economic programs over the years predominantly to better the living conditions of the citizens and douse the impacts of social and religious conflicts. The reason is that poor economic situations often contribute in no small measures to the faces of conflict and violence. These programs were intended to usher in fairness, create equity, promote justice, and enhance human capital development. Between 1983 and 1993, there were many economic reforms such as the Structural Adjustment Programme (SAP). SAP, in essence, "comprises various medium to long-term policies that have been designed by the International Monetary Fund (IMF) and World Bank Group to regulate a country's economic structure such that it can surmount chronic economic crisis through a reliance on market mechanisms" (Okome, 1998, p. 24). The positive intention of SAP was to realign the country's economy with the world capitalist economy and enhance the competitive market. SAP was designed as a two-year program from June 27, 1986 - June 1988 (Okome, 1998).

The Green Revolution (GR) was also introduced to diversify economic focus through investment in agribusinesses and promotion of agricultural products. This economic innovation encouraged citizens to invest in mechanised farming and reduce dependency on the petroleum industry as the mainstay of the economy.

The beginning of the new millennium witnessed many people-focused initiatives which target the liberation of unemployed youths from the poor economic situation. Poverty Alleviation Program (PAP) was introduced in 1999 as a scheme targeting poverty reduction among the citizens. This program was short-lived as it became replaced with the National Poverty Eradication Program (NAPEP). The goals of NAPEP include engaging the youths in vocational training and trades, support for an internship, support toward micro-credit facility, and creation of employment in the automobile industry. This scheme began with the Federal 
government's intention to support unemployed youths by creating medium scale businesses through a revolving loan for the participants. The objective of this scheme is to engage youth to participate in something that can generate a living for them so they will be self-sustaining, thereby reducing the attraction to participate in any form of violence. The percentages of success of PAP and NAPEP are different from one state to another.

\subsection{Disarmament, Demobilization, and Reintegration (Amnesty Program)}

On June 25, 2009, the administration of the President Umaru Musa Yar'adua offered an amnesty program to the teeming youths in the Niger-Delta who have been involved in the forefront of the quest for ownership of exploration of oil resources and revenues. The idea was to bring about disarmament, demobilization and reintegration of those youths earlier involved in the use of Small Arms and Light Weapons (SMLW). As a political strategy, amnesty was meant to create an atmosphere for peaceful coexistence (LaMonica \& Omotola, 2014 , p. 5-6). It is described in the following words:

"An amnesty is a guarantee of exemption from prosecution and pardon from punishment for certain criminal, rebel and insurgent actions hitherto committed usually against the state. It indemnifies affected persons in terms of safety and protection from punitive actions, retributions and associated losses. An amnesty is usually within a specific time within which offenders admit the crime and take advantage of the general pardon" (Otite \& Umukoro, 2010, p. 11-12).

The offer of amnesty was subject to the surrender of arms within sixty days of the declaration. A number of youths embraced the offer and surrendered their arms. Those who surrendered their arms were sent to South Africa and other countries for training in different trades with the promise that on their return, the government would create employment for them. Those who were earlier considered offenders had received pardon and reintegration instead of prosecution and punishment. The first batch of the 38 ex-militants went to South Africa for training in marine-associated courses, the second batch of 212 ex-militants was also sent for training in Ghana in industrial welding and fabrication. The federal government disarmament has not really yielded full dividends at this moment. Thus many have doubted the possibility of having total arms disarmament and therefore face the future risk of resurgence in eastern Nigeria.

Furthermore, others have suggested that the success of the amnesty strategy hinges on the willingness of the government to involve the members of the host communities, the youth groups, and the traditional leaders "and their buy-in into the program that would provide lasting peace in the Niger Delta" (Obuoforibo, 2010, p. 208). A similar view to this suggests further that unless the government takes bold steps to address the initial issues of marginalisation, inequalities, and consider jobs creation, to provide needed basic amenities and to step up its fight against corruption disarmament would not last (Otite \& Umukoro, 2010, p. 237-250).

The offer of amnesty was later proposed to those involved in interreligious violence in northern Nigeria a few years after it was introduced in the Niger-Delta area but it has yet to 
be implemented at this stage.

\subsection{Commission of Enquiries and Specialised Committees}

One of the most common strategies of the Nigerian government is the set-up of a commission of enquiries. In fact, it has become a norm for a state or the federal government in the event of civil, political or economic unrest. The essence of this strategy is to investigate the immediate and remote factors responsible for violence and to find a lasting solution or to prevent a future occurrence. However, most of the Commissions set up always do a good job by investigating the causes of conflicts and submitting their recommendations. The problems always lie with implementation. As indicated in the Jos crises, the recommendations of most of the Commissions of enquiry are more often than not beclouded with partisan politicking or nepotism and are either considered for implementation in part or pushed aside completely. This has given room for recurring episodes of the same or similar conflicts in Nigeria. The problems of corruption, ethnic identity and nepotism have had negative effects on most of the committees so that their essence has not been realised.

\subsection{Interreligious Dialogue}

One of the well-known approaches to socio-political and religious tension in Nigeria is interreligious dialogue. The new millennium has witnessed an increased emphasis and mobilization towards interreligious dialogue because of the recognition that various individuals have used religious elements to initiate crises. The debate on the Shari'a law and its application also complicated the situation beginning in the early part of the year 2000 . Contrary to the misleading opinion that once there is an ongoing interreligious dialogue there will be the restoration of peace and social order, interreligious dialogue in its various forms has not helped in the Nigerian situation. The cases of religious violence in the three states presented earlier as well as the introduction of Shari'a law in some states in northern Nigeria support this assertion. The overarching factors such as extremism, distrust, dishonesty, and political interest have ruined the process of genuine dialogue (Olorunnisola, 2019; McGarvey, 2009; Ezegbobelu, 2009). Possible options include the promotion of genuine dialogue of life that is rooted in an African ontological view of human relationship (Olorunnisola, 2019).

\section{Conclusion and Recommendations}

This article has outlined the cases of interreligious violence in northern Nigerian, focusing on major issues underlying constant strife in three northern states. The heart of the issues border on religion and how it has been appropriated to affect politics, ethnicity, economy, and governance. The main lesson from these case studies is that religion is a powerful tool that can be obtained to pursue a beneficial or disruptive agenda by a selected few. The unhealthy association and interaction that has existed over the years have had negative consequences in the process of nation-building since the eve of Nigerian independence. They have continued to sow multiple seeds of distrust, suspicion, abuse, intolerance, violence, and disintegration in various facets of Nigerian life. The most significant impact of this rivalry is evident in a backlash leading to a series of battles and losses that have accompanied it over the years.

There are a few ways in which an outbreak of religious violence can be curtailed. First, there 
is an urgent need for the government to develop a robust social architecture to arrest poor economic situations with strong political will. It has been observed that the economic downturn, increasing rate of employment marginality among the youths and the generally low standard of living have impacted upon series of violence earlier presented. This strategy will only be successful when the Nigerian government is proactive beyond partisan politics and with genuine interest to offer programs that will result in economic and political liberation of the masses.

Second, the three tiers of government in Nigeria (the federal, state, and local governments) must embark upon the promotion of tolerance and mutual respect for the humanity of the other in place of an ongoing investment in the interreligious dialogue. Dialogue in Nigeria requires a fresh approach which obtains every social and religious avenue to promote moral respect for the common humanity. Religious elements have always divided people against one another. Exploring a fresh starting point through the promotion of common humanity will create a neutral ground for peaceful coexistence rather focusing on religion.

Third, legal reforms, retributive justice and reparation need to be revisited. Adequate support systems need to be put in place not only to curtail a cycle of violence occurrence but also to prevent it from recurring. When people commit an offence and they go scot-free it creates a psychological awareness that such behavior is acceptable in society. Hence, due and uncompromising punishments should be put in place as retributions to deter other people from being enlisted into the frenzy of religious violence. In the event that violence occurs, the victims should be adequately compensated to free them from the trauma of the loss of property or businesses. Both retributive justice and reparation would be effective when there are judicial reforms. Those sections of the law that are outdated or that prescribe fewer punishments for criminal offenses must be outlawed in the light of current national developments. The legal and judicial reforms that are implied here also suggest an independent judiciary that is free from an unwarranted influence of the legislative and executive arms of government.

\section{References}

Adogame, A. (2005). Politicization of Religion and Religionization of Politics in Nigeria. In C. J. Korieh \& G. U. Nwokeji (Eds.), Religion History, and Politics in Nigeria, Essays in Honor of Ogbu U. Kalu (pp. 128-139). New York: University Press of America.

Agi, S. P. I. (1998). The Political History of Religious Violence in Nigeria. Calabar: Pigasiann \& Grace International Publishers.

Alubo, O. (2006). Ethnic Conflicts and Citizenship Crises in Central Region. Ibadan: Pefs.

Boer, J. H. (2003). Nigeria's Decades of Blood 1980-2002. Jos: African Christian Textbooks.

Daily Trust. (2013). Retrieved November 22, 2013, from http://www.dailytrust.com.ng/daily/old/index.php/news-news/16394-cttee-on-tafawa-balewacrisis-submits-report

Falola, T. (1998). Violence in Nigeria: The Crisis of Religious Politics and Secular Ideologies. 
Rochester: Rochester University Press.

Falola, T. (2009). Colonialism and Violence in Nigeria. Bloomington: Indiana University Press.

Human Rights Watch Report, 27 July 2003, 15(13).

Ikelegbe, A. (2010). Oil, Resource Conflicts and the Post Conflict Transition in the Niger Delta Region: Beyond Amnesty. Benin: Centre for Population and Environmental Development (CPED).

Kieh, Jr., \& George, K. (2002). Theories of Conflict Resolution. In G. K. Kieh, Jr. \& I. R. Mukennge (Eds.), Zones of Conflict in Africa: Theories and Cases (pp. 9-20). Westport: Praeger Publishers.

LaMonica, C., \& Omotola, J. S. (2014). Introduction: Why the Niger Delta Region of Nigeria Matters. In C. L. Monica \& J. S. Omotola (Eds.), Horror in Paradise: Framework for Understanding the Crises of the Niger Delta Region of Nigeria (pp. 5-6). Durham, NC: Carolina Academic Press.

Leadership. (2013). Retrieved November 22, 2013, from http://www.leadership.ng/news/270713/reverse-relocation-tafawa-balewa-lg-s-headquarters

Newsrescue. (2013). Retrieved November 23, 2013, from http://newsrescue.com/jos-crises-101-understanding-berom-fulani war/\#axzz21csqdvwJ

Nguvugher, C. D. (2010). Conflicting Christologies in a Context of Conflicts: Jesus, the Isawa, and Christian-Muslim Relations in Nigeria. Jos: Acts.

Obuoforibo, G. I. J. (2014). Small Arms and Light Weapons (SALW) Proliferation and Instability in the Niger Delta: An Analysis of the Disarmament, Demobilization and Reintegration (DDR) Process. In C. L. Monica \& J. S. Omotola (Eds.), Horror in Paradise: Framework for Understanding the Crises of the Niger Delta Region of Nigeria (pp. 207-220). Durham, NC: Carolina Academic Press.

Okome, M. O. (1998). A Sapped Democracy: The Political Economy of the Structural Adjustment Program and the Political Transition in Nigeria (1983-1993). New York: University Press of America.

Olorunnisola, T. S. (2019). Beyond Interreligious Dialogue: Dialogue of Life as a means to Peaceful Co-existence in Nigeria. European Journal of Scientific Studies (June), 15(17), 28-45. https://doi.org/10.19044/esj.2019.v15n17p28

Olorunnisola, T. S. (2016). Jesus in Nigerian Christianity: An Exploration of Some Aspects of Christology That May Contribute to Peace and Mutuality. Unpublished $\mathrm{PhD}$ Thesis, University of Divinity, Australia.

Osaghae, E. E., \& Suberu, R. T. (2005). A History of Identities, Violence and Stability in Nigeria. Centre for Research and Inequality Human Security and Ethnicity Working Paper, 6. The Kaduna Peace Declaration of Religious Leaders, August 22, 2002. 
Otite, A., \& Umukoro, N. (2014). The Amnesty Programme and the Future of the Niger Delta: An Overview of the Disarmament, Demobilization, and Reintegration (DDR) Strategy for Sustainable Peace. In C. L. Monica \& J. S. Omotola (Eds.), Horror in Paradise: Framework for Understanding the Crises of the Niger Delta Region of Nigeria (pp. 237-250). Durham, NC: Carolina Academic Press.

Riots force Miss World out of Nigeria. (2002). Retrieved November 20, 2013, from http://news.bbc.co.uk/onthisday/hi/dates/stories/november/23/newsid_3226000/3226740.stm.

The Truth behind the Miss World riots. (2013). Retrieved November 20, 2013, from http:/www.theguardian.com/world/2002/nov/30/jamesastill

ThisDay. (2013). Retrieved November 22, 2013, from http://www.thisdaylive.com/articles/20-feared-killed-in-bauchi/90917/

Tidwell, A. (1998). Conflict Resolved? A Critical Assessment of Conflict Resolution. London: Continuum.

Vanguard. (2011). Retrieved November 22, 2013, from http://www.vanguardngr.com/2011/05/16-die-20-houses-burnt-in-bauchi\%E2\%80\%99s-fresh -mayhem/\#sthash.QnqdmJZR.dpuf

Vanguard. (2013). Retrieved November 22, 2013, from http://www.vanguardngr.com/2013/06/yuguda-defends-relocation-of-tafawa-balewa-lg-hqtrs/ \#sthash.g4NsNajR.dpuf

Vanguard. (2013). Retrieved November 23, 2013, from http://www.vanguardngr.com/2010/03/jos-crisis-when-a-mining-city-becomes-an-eternal-kill ing-field/\#sthash.QufocEMw.dpuf

Vanguard. (2013). Retrieved November 23, 2013, from http://www.vanguardngr.com/2011/03/1654-persons-n970bn-worth-of-property-lost-in-jos-cr ises-since-1994-jos-group/

\section{Notes}

Note 1. A brand of Shari'a law implemented in Kaduna allowed people of opposite gender to sit in the same car unlike the case of Zamfara State.

Note 2. NAPEP was a federal government initiative to support unemployed youths by engaging them in small scale businesses. Government facilitates the business by giving loan to individual participants in the program.

Note 3. Some reports noted that the situation degenerated to the extent that a group of people in Berom were roasting human parts for food without restriction. The police were said to have seen this case but took no step either for arrest or prosecution.

Note 4. The incumbent governor Jonah Jang set up a Commission of Enquiry headed by Bola Ajibola. The Commission in its 339-page report faulted the establishment of Jos North Local Government where the crises first began in Plateau State and revolved around it ever since. 
This local government was created by the former military government of General Ibrahim Babangida as a move to favor the Hausa-Fulani group in Jos North who clamored for recognition against the indigenes in 1991. It further recommended the following: 1. The Jos North Local Government be delineated into three with an equal numbers of wards. 2. Every appointment, promotion, and nomination by the state government should reflect due and equal consideration for all ethnic groups in the state. 3. The state government should include and promote State Character in the manner of the Federal Character Principle to enhance every citizen in the state to have the same inalienable rights everywhere they find themselves.

Note 5. The Hausa/Fulani group refused to show up before the Commission of Enquiry set up by the State government possibly because they did not trust the Commission to play the role of an unbiased umpire in its findings and recommendations. But immediately the General Emmanuel Abisoye Panel started meeting, the Hausa/Fulani groups flooded it with petitions and memorandums. The group was advised that the whole happening was political in nature going through the history of the crises. It alleged that the current Governor Jonah was supporting the Christian groups.

Note 6. This group gave the break down as follows: 630 Yoruba, 604 Igbo and 430 people from the South-South lost their lives to the crises which occurred at various times over a period of a decade in the Jos area. According to the spokesperson of this group, the Yoruba lost property worth N450 billion, Igbo N10 billion and South-South N110 billion in the $\begin{array}{llll}\text { various } & \text { crises } & \text { since } & \text { See }\end{array}$ http://www.vanguardngr.com/2011/03/1654-persons-n970bn-worth-of-property-lost-in-jos-cri ses-since-1994-jos-group/. Accessed on 23rd November, 2013.

\section{Copyrights}

Copyright for this article is retained by the author(s), with first publication rights granted to the journal.

This is an open-access article distributed under the terms and conditions of the Creative Commons Attribution license (http://creativecommons.org/licenses/by/4.0/). 